Isidora Ljumović ${ }^{1}$

Institute of Economic Sciences, Belgrade, Serbia

\section{Krsto Jakšić 2}

Slaviša Trajković ${ }^{3}$

University of Pristina - Kosovska Mitrovica, Faculty of Economics, Serbia
ORIGINAL SCIENTIFIC ARTICLE

DOI: 10.5937/ekonomika2104055L Received: September, 24. 2021.

Accepted: October, 14. 2021.

\title{
SOCIO-DEMOGRAPHIC CHARACTERISTICS OF DIGITAL FINANCIAL SERVICES USERS: EVIDENCE FROM SERBIA
}

\begin{abstract}
Given the importance of digital financial services on financial inclusion, the authors examined the socio-demographic characteristics of users of digital financial services in the Republic of Serbia. The authors hypothesized that age, education, employment, and income are key socio-demographic characteristics that have influenced digital financial services. The Global Findex database of the World Bank was used to analyse the socio-demographic characteristics of digital financial service users in the Republic of Serbia, with a sample of 1000 inhabitants older than 15 years. To test differences between the analyzed characteristics, a t-test was applied using SPSSv25. The results show a difference among most of the analyzed characteristics. Socio-demographic characteristics, apart from gender and income, are statistically significant. The results show a statistically significant difference in the age of users of digital financial services and non-users of digital financial services. Also, users of digital financial services are highly educated and more often employed. Based on the results, it can be concluded that the average user of digital financial services is younger, more educated, more often employed and uses various banking services, such as credit and debit cards, savings and borrowing more often than non-users of these services.
\end{abstract}

Key words: digital financial services, Findex, Serbia, socio-demographic characteristics

JEL classification: 016,650

\section{СОЦИО-ДЕМОГРАФСКЕ КАРАКТЕРИСТИКЕ КОРИСНИКА ДИГИТАЛНИХ ФИНАНСИЈСКИХ УСЛУГА: ИСКУСТВА ИЗ РЕПУБЛИКЕ СРБИЈЕ}

\begin{abstract}
Апстракт
\footnotetext{
${ }^{1}$ isidora.ljumovic@ien.bg.ac.rs, ORCID ID 0000-0002-8603-9672)

${ }^{2}$ krsto.jaksic@pr.ac.rs, ORCID ID 0000-0001-5508-0069)

${ }^{3}$ slavisa.trajkovic@pr.ac.rs, ORCID ID 0000-0001-5210-6454)
}

С обзиром на значај дигиталних финансијских услуга на финансијску инклузију аутори су испитивали соџио-демографске карактеристике корисника дигиталних 
финансијских услуга у Републици Србији. Аутори су претпоставили да су старост, образовање, запослење и приходи кључне социо-демографске карактеристике које утичу на употребу дигиталних финансијских услуга. За анализу сочиодемографских карактеристика корисника дигиталних финансијских услуга у Републиичи Србији коришћена је база података Global Findex Светске Банке са узорком од 1000 становника старијих од 15 година. Да би тестирали разлике међу карактеристикама корисника дигиталних финансијских услуга примењен је т-тест програмом СПСС в25. Резултати показују разлику међу већином анализираних карактеристика. Све анализиране сочио-демографске карактеристике осим пола и прихода, су статистички значајне. Пре свега, значајна је разлика у старости корисника дигиталних финансијских услуга и оних који не користе дигиталне финансијске услуге. Такође, корисници дигиталних финансијских услуга имају вити ниво образоваға и чешће су запослени. На основу резултата могуће је закључити да је просечан корисник дигиталних финансијских услуга млађи, образованији, чешће запослен и учесталије користи разне банкарске услуге, као што су кредитне и дебитне картице, итедна и задуживаье у односу на популацију која не користи ове услуге.

Кључне речи: дигиталне финансијске услуге, Findex, Србија, сочуи-демографске карактеристике

\section{Introduction}

In the era of digitization and rapid technological advancements, there have been significant changes in all parts of corporate processes, as well as the creation of new business opportunities. Changes in the financial industry, as well as acceptance of digital technology, have occurred in parallel with changes in the real sector. This is known as the financial sector's digital transformation, which brings new business models and products/services to the market. Various forms of digital money have arisen over the last decade, including digital advising and trading systems, peer-to-peer (P2P) financing, crowdsourcing, mobile payment systems, and even new monetary capabilities (such as Bitcoin and other crypto-assets) (Junger\&Mietzner, 2020). They are often called alternative sources of finance as they arose outside the traditional financial system, which includes banks and financial markets. Today, financial markets are complex, offering a wide range of services as mentioned above. Having this in mind, it is not easy to survive in the new digital world. New knowledge and skills are needed to analyze all possibilities and make the best decisions for financial security.

Innovative technology research and use has a significant impact on the development of digital financial services, particularly in industrialized countries. Digital financial services appear in a wide spectrum of digital asset utilization, from the use of mobile phones to the use of various information and communication technology apps with electronic payment capabilities. David-West (2016) defines DFS as the leverage of information and communication technologies for cost-effective delivery channels that include electronic payments systems (retail and wholesale) and electronic banking products or services. services. Financial services offered via mobile phones, personal 
computers, the internet, or cards linked to a secure digital payment system are also regarded as a part of digital finance (Ozili, 2018). DFS activities can significantly help to increase financial inclusion by providing access to other financial services such as payments, savings, loans, insurance and investments.

The development of digital payment, money transfer systems, and the growing use of mobile phones has enabled financial institutions to design products that are accessible to a wide variety of users. These new digitally delivered products and services have the potential to contribute to financial inclusion and, ultimately, social economic development. In many developing countries, financial inclusion appears to be a potential transformative agent that can lead to poverty reduction, ensure a more financially inclusive society (Sassi \& Goaied 2013) and improve financial access to traditional financial institutions (N'dri \& Kakinaka, 2020). In rural and excluded communities, mobile money can be the best tool for individual financial inclusion because it allows individuals to easily transfer money (Munyegera \& Matsumoto, 2016).

Since the commitment to the Maya Declaration and the G-20 Financial Inclusion Plan, the concept of financial inclusion has sparked a lot of interest, highlighting two essential aspects of financial inclusion: "access" to financial products and "usage" of customers to obtain economic advantages (Demirguc-Kunt \& Klapper, 2012). According to a United Nations Report, financial inclusion is the sustainable provision of affordable financial services that brings the poor into the formal economy (United Nations, 2016). Since then, many academics and economic policymakers have emphasized the importance of financial inclusion for many reasons. Ozili (2020) highlights the main reasons: strategy of sustainable development goals by the United Nations; improved social inclusion; poverty reduction; and finally, the link with socio-economic benefits. It is well established that increasing the number of (mainly poor) people who have access to formal financial services leads to higher financial inclusion. As a result of increased financial inclusion, previously financially excluded individuals will be able to invest in education, save, and start enterprises, helping to reduce poverty and boost economic growth (Beck et al., 2007; Bruhn \& Love, 2014). In this regard, we investigated the socio-demographic characteristics of digital financial service users in Serbia.

\section{Theoretical backgrounds and Literature review}

Digital finance, according to Gomber et al. (2017), includes a wide range of new financial products, enterprises, software, and unique modes of consumer communication and interaction, all of which are provided by FinTech companies and creative financial service providers. There are other definitions too, but as Ozli (2018) mentions, digital finance includes all products, services, technology, and/or infrastructure that enable individuals and companies to have access to payments, savings, and credit facilities via the internet (online) without the need to visit a bank branch or without dealing directly with the financial service provider. As a result, three elements must exist and be employed to establish digital services: the platform (technology for transactions), the agent (bank or other financial institution), and the mediator (internet or mobile phone).

The importance of digital finance and financial inclusion for poverty reduction and fostering economic growth and development has attracted the attention of numerous 
institutions, policy makers, and the academic community (Ozli, 2018). The benefits of digital finance and financial inclusion are primarily reflected in the increased access to finance for the poor, lower financial intermediation costs for banks and providers of FinTech technologies. The goal of financial services made available through digital platforms is to help emerging nations achieve their poverty reduction and financial inclusion goals (United Nations, 2016). While financial inclusion emphasizes having an account (Sarma, 2015), affordable services and the formal economy (DemirgucKunt et al. 2017), digital financial inclusion focuses on technology as a facilitator for expanding access to financial services to excluded or underserved individuals (Wang and He 2020), as well as tailor-made products that can meet the needs of these individuals (Alameda 2020). Also, it is considered that automation, new data technology processing, and artificial intelligence unravel credit assets of clients and eliminate the need for historical records (Sapovadia, 2018). DFS allows small transactions to be completed at a low cost and in a shorter amount of time, which is beneficial for small enterprises and the vulnerable population (Dawei et al., 2018). Despite these advantages, digital financing is not broadly available to all segments of the population (G20 Summit, 2013), demonstrating a gap between finance availability, accessibility, and use (Kumar \& Rao, 2015). There is also a problem with high start-up costs in establishing new technologies. However, the economy of scale brings marginal costs towards zero (Liao et al., 2020).

In the 2016 State of the Market Report on Digital Financial Services in Nigeria, David-West et al. (2016) reported that "the under-banked and unbanked citizens of Nigeria are predominantly women and youths between the ages of 18 and 35, with minimal education, either unemployed or in low-income earning jobs". Age, gender, and income have been found to have negative effects on mobile money transfer user approval. However, education levels and employment status are major sociodemographic characteristics that predict the frequency of use, use, and acceptance of mobile money transfers in Zimbabwe (Marumbwa, 2014). Another study on the sociodemographic aspects of e-inclusion found that while there are no statistically significant gender differences in Internet use, the degree of education, along with income status, has a positive association with Internet use (Silva et al., 2017). In the research that is indirectly related to the topic of this paper and deals with using modern technologies in personal financial management, the authors check the socio-demographic characteristics of individuals to decide whether to entrust financial decisions to a computer program. Age, employment, and income have the strongest influence on their decision to use modern financial technology, whereas gender and level of education were not shown to be statistically significant (Waliszewski \& Warchlewska, 2020). In an effort to analyse the socio-demographic characteristics of people who use digital technologies, Mouna \& Jarboui (2021) conclude that better collaboration between the government and the financial sector can help to develop digital financial inclusion through technology adoption channels, as they found that the poor, the less educated, and the young are disproportionately excluded from the financial system. In India, gender, age, education, income, and employment status have a significant influence on the accessibility of digital financial inclusion (Nandru, et al., 2021). 


\section{Research Design, Methodology, Research Tasks and Hypothesis}

Based on the literature review, we can expect major differences in socio-demographic characteristics of users of digital financial services in Serbia. We suppose that age, education, employment, and income are major factors, followed by the use of financial services. As in the prior studies, we do not expect gender to have a significant role, as the tradition and mentality of the environment in Serbia do not limit them from using digital services.

The World Bank's Global Findex database was used to discover the socio-demographic characteristics of users of digital financial services in Serbia. The database contains information on adult inhabitants' savings, borrowing, payment, and risk management habits (aged 15 and over). Since 2011, data has been collected every three years. The most recent study was completed in 2017, with a follow-up study scheduled for 2020 . The results of the 2020 database, however, have yet to be disclosed. As a result, we will use the most recent available data from 2017 in our study. The 2017 edition of the database includes statistics on the use of financial technology (fintech), which was not included in prior versions. The Serbian database provides micro-level data containing socio-demographic and economic indicators of the Serbian adult population aged 15 and up $(\mathrm{N}=1,000)$ drawn from nationally representative, randomly selected samples.

The World Bank's questionnaire collected over 100 variables. However, in this study, we evaluated socio-demographic features of users of digital financial services (DFS) in Serbia using the information on digital services, socio-demographic characteristics, and the use of financial services. The question in the survey, whether an individual "used the Internet to pay bills or to buy something online in the 12 months before the research" was used as a variable pointing to the use of digital financial services. If the respondent answered yes, the variable takes the value of 1 , elsewise zero. Socio-demographic variables include gender, age, education, income level, and employment status. The level of education is measured using official educational grading, categorized into three groups: completed primary or less (up to eight years of schooling), secondary (up to 12 years of schooling) and tertiary or more (over 15 years of schooling). The income level is grouped into five quintiles per $20 \%$. Employment status reflects whether the respondent is in or out of the workforce. To measure the use of financial services, we used responses to the question about owning a debit and credit card and questions related to savings and borrowing patterns (answers to the questions: did you save or set aside any money in the 12 months before the research and did you borrow any money in the 12 months before the research). All variables used to measure the use of financial services have a value of 1 if the respondent answered yes, zero elsewise. To test the differences between the characteristics of digital financial service users, we applied a t-test. The analysis was performed using SPSS v.25.

Table 1 shows descriptive statistics, socio-demographic characteristics, and the use of financial services of the survey participants. The sample consists of 1,000 individuals, with $19.3 \%$ of users of digital financial services $(n=193)$. The proportion of females in all samples, including the whole sample, the sample of users of financial services, and the sample of nonusers of financial services, is similar and ranges from 45.6 per cent, 43.5 per cent, and 46.1 per cent, respectively, compared to the proportion of males. The mean value for age is 49.8 years in the total sample. However, the users of digital financial services are much younger, with an average age of 36.1, compared to the non-users of DFS (mean age of 53 years). The majority of respondents have secondary education, but in the sample of users of digital financial services, 
the significant participation of individuals with tertiary education is noticeable. Most of the users of digital financial services come from the fifth (the richest) income quintile. Also, users of digital financial services are predominately included in the workforce $(71 \%)$, opposite to the general sample, and a sample of non-users of DFS. Looking at the variables related to financial inclusion, users of digital financial services much more often use credit $(75.6 \%)$ and debit $(36.8 \%)$ cards, more often save $(46.1 \%)$ and more frequently borrow $(56.5 \%)$. Generally speaking, besides age, the subsample of users of digital financial services does not correspond to the general sample (Table 1). As we can observe from the descriptive statistics that differences between groups of users and non-users of digital financial services exist, and our independent variable is a dichotomous variable with two levels, a t-test is appropriate.

Table 1: Descriptive statistic of the sample

\begin{tabular}{|c|c|c|c|c|}
\hline Variables & Description & $\begin{array}{l}\text { Users of DFS } \\
(\%)\end{array}$ & $\begin{array}{l}\text { Non-users of } \\
\text { DFS }(\%)\end{array}$ & $\begin{array}{l}\text { Total } \\
(\%)\end{array}$ \\
\hline \multirow{2}{*}{$\begin{array}{l}\text { Bought something online } \\
\text { using the Internet }\end{array}$} & yes & 100 & 0 & 19.3 \\
\hline & no & 0 & 100 & 80.3 \\
\hline \multirow{2}{*}{ Gender } & female & 43.5 & 46.1 & 45.6 \\
\hline & male & 56.5 & 53.9 & 54.4 \\
\hline Age & (mean value) & 36.1 & 53.0 & 49.8 \\
\hline \multirow{3}{*}{ Education } & primary & 2.6 & 22.8 & 18.9 \\
\hline & secondary & 66.8 & 64.3 & 64.8 \\
\hline & tertiary & 30.1 & 13 & 16.2 \\
\hline \multirow{5}{*}{$\begin{array}{l}\text { Within-economy household } \\
\text { income quintile }\end{array}$} & Poorest $20 \%$ & 15.5 & 14.1 & 14.3 \\
\hline & Second $20 \%$ & 14 & 19.6 & 18.4 \\
\hline & Middle $20 \%$ & 16.6 & 20.2 & 19.6 \\
\hline & Fourth $20 \%$ & 21.8 & 22 & 22.1 \\
\hline & Richest 20\% & 32.1 & 24.2 & 25.6 \\
\hline \multirow{2}{*}{ Employment status } & out of workforce & 29 & 58.5 & 52.9 \\
\hline & in workforce & 71 & 41.5 & 47.1 \\
\hline \multirow[b]{2}{*}{ Has a debit card } & yes & 75.6 & 64.5 & 66.6 \\
\hline & no & 24.4 & 35.5 & 33.4 \\
\hline \multirow[b]{2}{*}{ Has a credit card } & yes & 36.8 & 15.2 & 19.3 \\
\hline & no & 62.7 & 84.3 & 80.5 \\
\hline \multirow{2}{*}{ Saved in the past year } & yes & 46.1 & 29.6 & 32.9 \\
\hline & no & 53.9 & 70.4 & 67.1 \\
\hline \multirow{2}{*}{ Borrowed in the past year } & yes & 56.5 & 37.9 & 41.3 \\
\hline & no & 43.5 & 62.1 & 58.7 \\
\hline
\end{tabular}

Source: Authors' calculation 


\section{Research results and Discussion}

The t-test confirms significant differences among these groups (Table 2). The results show a difference among the majority of analysed characteristics. Socio-demographic characteristics, except for gender and income, are statistically significant. There is a significant difference in the age of users of digital financial services $(\mathrm{M}=36.2, \mathrm{SD}=11.9)$ and non-users of DFS $(\mathrm{M}=53, \mathrm{SD}=17.3, \mathrm{t}(994)=-12.8, \mathrm{p}<0.01)$. Users of digital financial services have obtained higher education (2.29 opposite to $1.91, \mathrm{t}(994)=8.35, \mathrm{p}<0.01)$ and are more often employed $(0.71$ against $0.41, \mathrm{t}(994)=7.58, \mathrm{p}<0.01)$. All variables related to the use of financial services are statistically significant. Users of financial services more often use debit and credit cards $(0.76$ compared to $0.65, \mathrm{t}(994)=2.63, \mathrm{p}<0.01$ for debit cards, and 0.39 versus $0.16, \mathrm{t}(994)=7.04, \mathrm{p}<0.01$ for credit cards). Moreover, a larger number of respondents belonging to the users of digital financial services have savings ( 0.746 compared to $0.3, \mathrm{t}(994)=4.42, \mathrm{p}<0.01)$ and borrow from the formal financial system $(0.56$ to $0.38, \mathrm{t}$ $(994)=4.73, \mathrm{p}<0.01)$.

Table 2: Differences between users and non-users of digital financial services

\begin{tabular}{|l|l|l|l|l|l|}
\hline & \multicolumn{2}{|l|}{ Users of DFS } & \multicolumn{2}{l|}{ Non-users of DFS } & \\
\hline & $\mathrm{M}$ & SD & M & SD & t-test \\
\hline Gender & 1.56 & 0.497 & 1.54 & 0.499 & 0.639 \\
\hline Age & 36.15 & 11.918 & 52.98 & 17.304 & $-12.801^{* * *}$ \\
\hline Education & 2.29 & 0.539 & 1.90 & 0.590 & $8.349^{* * *}$ \\
\hline Income & 3.41 & 1.452 & 3.23 & 1.377 & 1.637 \\
\hline Employment status & 0.71 & 0.455 & 0.41 & 0.493 & $7.577^{* * *}$ \\
\hline Has a debit card & 0.76 & 0.430 & 0.65 & 0.499 & $2.632^{* * *}$ \\
\hline Has a credit card & 0.39 & 0.549 & 0.16 & 0.373 & $7.039^{* * *}$ \\
\hline Saved in the past year & 0.46 & 0.500 & 0.300 & 0.457 & $4.415^{* * *}$ \\
\hline Borrowed in the past year & 0.56 & 0.497 & 0.38 & 0.485 & $4.763^{* * *}$ \\
\hline
\end{tabular}

*** $\mathrm{p}>0.01$

Note: $\mathrm{M}=$ mean; $\mathrm{SD}=$ standard deviation

Source: Authors' calculation

In our research, we found that the average user of digital financial services is younger, better educated, more frequently employed, and uses a variety of banking services, such as credit and debit cards, saving, and borrowing, more regularly than non-users of DFS and the overall public. This supports our initial claim that there are significant socio-demographic differences among users and non-users of digital financial services in Serbia.

According to the research, age has the greatest impact on the use of digital financial services, as in Waliszewski \& Warchlewska (2020); Mouna \& Jarboui (2021) and Nandru, et al., (2021), but in contrast to the research related to mobile money transfers approval and use (Marumbwa, 2014). This finding is supported by the fact that ICTs play a special role in young people's lives (Coleman, 2012), whereas the current digital generation will be able to transform traditional social institutions, develop the priorities of the digital economy and become the creators of advanced technologies (Korshunova, 
2020). Education is the second most influential factor on digital financial service usage patterns, which is consistent with the majority of research (Marumbwa, 2014; Silva et al., 2017, Mouna \& Jarboui 2021; Nandru, et al., 2021). However, these results differ from Waliszewski \& Warchlewska, (2020), who did not find any statistical significance among these variables. Digital financial services are used to a greater extent by people declaring themselves to be employed. It implies they have a greater demand for these services and are willing to spend money on online shopping (Nandru, et al., 2021). We did not find any statistically significant relationship between gender and dependent variable, as in Marumbwa, 2014; Silva et al., 2017; Waliszewski \& Warchlewska, 2020, nor with income and the use of digital financial services. In addition, we tested for the differences between users and non-users of digital financial services and the use of financial products. Here, we found a major difference, where users of digital services more often approach the formal financial system.

\section{Conclusion}

In this paper, we provided an empirical analysis of the differences in socio-demographic characteristics of users of digital financial services in Serbia. Given the importance of digital products for financial inclusion, we examined data on 1,000 individuals from Serbia from the World Bank Global Findex database to understand the basic differences in chosen characteristics. In conclusion, the typical users of digital banking services are younger people who are more educated and employed, whereas gender and income do not have major roles in digital inclusion. Furthermore, because they use various banking services, credit and debit cards, saving and borrowing, consumers of digital banking services are more financially included. Such results have practical implications for defining public policies that can help boost digital financial services, and thus increase financial inclusion through technology adoption channels. This study confirms the importance of government policy towards digital services in advancing financial inclusion in Serbia. As the covid-19 pandemic didn't cause just social distancing but also financial distancing (Howell et al., 2021), the importance of policies to promote digital services is becoming even more important. Although this study contributes to the literature on digital financial inclusion, there is a limitation regarding the sampling period. It would be interesting to compare the findings of the study with newer data from 2020 in the future. Next, because the dataset is limited to Serbia, no general conclusions about the world's population can be formed. However, considering that public policies have local character, we must take into account the specificities of the local financial system and local habits regarding the use of digital technologies. To make financial inclusion more wide-ranging, governments should focus on the elderly population, which is less educated and out of the workforce.

\section{References}

Alameda, T. (2020). Data, ai and financial inclusion: the future of global bankingResponsible Finance Forum, Responsible Finance Forum BBVA 2020. Available online: https://responsiblefinanceforum.org/data-ai-financial-inclusion-futureglobal-banking/ (Accessed 3 Jun 2021). 
Beck, T., Demirgüc-Kunt, A., \& Levine, R. (2007). Finance, inequality and the poor. Journal of Economic Growth, 12(1), $27 \mathrm{e} 49$.

Bruhn, M., \& Love, I. (2014). The real impact of improved access to finance: Evidence from Mexico. The Journal of Finance, 69(3), 1347e1376.

Coleman J. (2012) Introduction: Digital technologies in the lives of young people, Oxford Review of Education, 38(1), 1-8

David-West, O. (2016). E-commerce management in emerging markets. In I. Lee (Ed.). Encyclopedia of E-commerce development, implementation, and management, 200-222. IGI Global. http://dx.doi.org/10.4018/978-1-4666-9787-4. (Accessed 3 Jun 2021)

Dawei, L., Hu, A., \& Li, G. (2018). Big Data Technology: Application and Cases. In Handbook of Blockchain, Digital Finance, and Inclusion. Amsterdam: Elsevier Inc., pp. 65-82.

Demirguc-Kunt, A., Klapper, L., Ansar, S., \& Jagati, A. (2017). Making It Easier to Apply for a Bank Account: A Study of the Indian Market. Available online: https://elibrary.worldbank.org/doi/abs/10.1596/1813-9450-8205 (accessed on 12 May 2021).

Demirguc-Kunt, A., Klapper,L., (2012). Measuring Financial Inclusion: the Global Findex Database, World bank policy research working paper, (6025). The World Bank.

G20 Summit. (2013). G20 Leaders' Declaration. September, St Petersburg, Russia. Available: $\quad$ http://www.g20.utoronto.ca/2013/2013-0906-declaration.html. (Accessed 9 May 2021).

Gomber, P., Koch, J. A., \& Siering, M. (2017). Digital finance and FinTech: Current research and future research directions. Journal of Business Economics, 67(5), $537 \mathrm{e} 580$.

Howell, S. T., Lerner, J., Nanda, R., \& Townsend, R. (2021). How Resilient is VentureBacked Innovation? Evidence from Four Decades of US Patenting. Harvard Business School Entrepreneurial Management Working Paper, (20-115).

Junger,M.,\& Mietzner,M.(2020). Banking goes digital: The adoption of FinTech services by German households. Finance Research Letters, 34, 101260

Korshunova, S. A. (2020). Youth of today in the context of digital society development. In Proceedings of INTCESS 2020 - 7th International Conference on Education and Social Sciences 20-22 January, 2020 - Dubai.

Kumar, S., \& Rao, P. (2015). A conceptual framework for identifying financing preferences of SMEs. Small Enterprise Research, 22(1), 99-112.

Liao, G., Yao, D., \& Hu, Z. (2020(. The Spatial Effect of the Effciency of Regional Financial Resource Allocation from the Perspective of Internet Finance: Evidence from Chinese Provinces. Emerging Markets Finance and Trade 56: 1211-23.

Marumbwa, J. (2014). Exploring the moderating effects of socio-demographic variables on consumer acceptance and use of mobile money transfer services (MMTs) in Southern Zimbabwe. American Journal of Industrial and Business Management, 4(2), Article ID:42739. 
Mouna, A., \& Jarboui, A. (2021). Understanding the link between government cashless policy, digital financial services and socio-demographic characteristics in the MENA countries. International Journal of Sociology and Social Policy, Vol. ahead-of-print No. ahead-of-print.

Munyegera, G. K., \& Matsumoto, T. (2016). Mobile money, remittances, and household welfare: Panel evidence from rural Uganda. World Development, 79(C), 127-137.

N'dri, L. M., \& Kakinaka, M. (2020). Financial inclusion, mobile money, and individual welfare: The case of Burkina Faso. Telecommunications Policy, 44(3), 101926.

Nandru, P., Chendragiri, M., \& Velayutham, A. (in press). Determinants of digital financial inclusion in India: Evidence from the World Bank's global findex database. Journal of Economic Structures.

Ozili, P. K. (2018). Impact of digital finance on financial inclusion and stability. Borsa Istanbul Review, 18(4), 329-340.

Ozili, P. K. (2020). Financial inclusion research around the world: a review. In Forum for social economics, 1-23. Routledge.

Sapovadia, V. (2018). Financial Inclusion, Digital Currency, and Mobile Technology. In Handbook of Blockchain, Digital Finance, and Inclusion. Amsterdam: Elsevier Inc., pp. 361-85.

Sarma, M. (2015). Measuring financial inclusion. Economics Bulletin 35, 604-611.

Sassi, S., \& Goaied, M. (2013). Financial development, ICT diffusion, and economic growth: Lessons from MENA region. Telecommunications Policy, 37(4), 252-261.

Silva, P., Matos, A. D., \& Martinez-Pecino, R. (2017). E-inclusion: Beyond individual socio-demographic characteristics. PloS one, 12(9), e0184545.

United Nations. (2016). Digital financial inclusion. international telecommunication union (itu), issue brief series, inter-agency task force on financing for development, July. United Nations. Available at: http://www.un.org/esa/ffd/wpcontent/uploads/2016/01/Digital-Financial-Inclusion_ITU_IATFIssue-Brief.pdf . (Accessed 5 Jun 2021).

Waliszewski, K., \& Warchlewska, A. (2020). Socio-Demographic Factors Determining Expectation Experienced while Using Modern Technologies in Personal Financial Management (PFM and robo-advice): A Polish Case. European Research Studies, 23(2), 893-904.

Wang, X., \& H, G. (2020). Digital financial inclusion and farmers' vulnerability to poverty: Evidence from rural China. Sustainability 12(4), 1668. 